\title{
PENERAPAN MODEL QUANTUM TEACHING SEBAGAI UPAYA MENINGKATKAN HASIL BELAJAR SISWA PADA MATA PELAJARAN IPS KELAS VIII SMP PGRI 3 JAKARTA
}

\author{
Putri Lestari ${ }^{1}$ dan Adeng Hudaya ${ }^{2}$ \\ ${ }^{1}$ Alumni Mahasiswa Program Studi Pendidikan Ekonomi Universitas Indraprasta PGRI \\ ${ }^{2}$ Dosen Program Studi Pendidikan Ekonomi Universitas Indraprasta PGRI \\ Email : putri.lestari@gmail.com
}

\begin{abstract}
Abstrak
Tujuan penelitian ini adalah untuk mengetahui pengaruh Penerapan Model Quantum Teaching Sebagai Upaya Meningkatkan Hasil Belajar Siswa Pada Mata Pelajaran IPS Kelas VIII SMP PGRI 3 Jakarta. Penelitian ini adalah penelitian kuantitatif dengan jenis metode eksperimen dengan jumlah sampel 42 peserta didik. Dalam arti yang sederhana, penelitian kuantitatif itu berkenaan terutama dengan data angka atau numerical. Berdasarkan analisis data dari pembahasan yang telah dilakukan, maka dapat ditarik kesimpulan terdapat pengaruh yang signifikan model pembelajaran Quantum Teaching terhadap hasil belajar peserta didik pada mata pelajaran IPS. Hal ini ditunjukan dari hasil perolehan pengujian hipotesis dengan menggunakan uji-t yaitu diperoleh nilai $t_{\text {hitung }}=3,140$ lebih besar dari $t_{\text {tabel }}=2,021$ dengan taraf signifikan 0,05. Selain itu dapat dilihat dari rata-rata hasil belajar peserta didik pada mata pelajaran IPS yang menggunakan model pembelajaran Quantum Teaching sebesar 77,28 lebih tinggi dari pada rata-rata hasil belajar peserta didik pada mata pelajaran IPS yang menggunakan metode konvensional sebesar 66,71
\end{abstract}

Kata Kunci: Model Quantum Teaching dan Hasil Belajar

\section{PENDAHULUAN}

Di era globalisasi ini, perkembangan ilmu pengetahuan dan teknologi berlangsung sangat pesat seiring dengan kemajuan zaman. Perkembangan ini sangat erat kaitannya dengan seluruh aspek kehidupan termasuk salah satunya adalah menyangkut tentang pendidikan karena pendidikan erat kaitannya dalam hal untuk mempersiapkan kualitas sumber daya manusia (SDM) agar dapat bersaing di era globalisasi ini.

Pendidikan merupakan kebutuhan yang sangat penting dan berlangsung sepanjang masa. Pendidikan pada dasarnya dapat membantu manusia dalam mengembangkan dirinya, sehingga mampu menghadapi perubahan yang terjadi dalam kehidupannya. Pendidikan yang baik akan menghasilkan sumber daya manusia yang berkualitas baik bagi diri sendiri, bangsa, dan negara sehingga mampu bersaing dan berkompetisi dengan negara lain. Dengan demikian, pendidikan harus benar-benar diarahkan untuk menghasilkan manusia yang berkualitas dan mampu bersaing disamping memiliki budi pekerti luhur dan moral yang baik. 
Banyak upaya yang telah ditempuh untuk dapat meningkatkan mutu pendidikan. Berbagai upaya yang dilakukan terjadi pada berbagai aspek pendidikan, diantaranya yaitu pengembangan kurikulum yang ditingkatkan sesuai dengan kondisi perkembangan zaman, proses pembelajaran yang meliputi Kegiatan Belajar Mengajar (KBM), model pembelajaran yang digunakan disesuaikan dan ditingkatkan sesuai dengan tujuan, pengembangan media pembelajaran yang digunakan atau alat-alat pendukung media pembelajaran untuk dapat membantu meningkatkan prestasi belajar siswa, fasilitas ruang belajar yang memadai serta kompetensi guru yang semakin ditingkatkan, pembelajaran yang digunakan juga harus memiliki kesesuaian dengan modelnya serta dapat memajukan siswa dalam memahami pembelajaran.

Pendidikan memiliki kaitan yang sangat erat dengan sekolah sebagai tempat untuk memperoleh pendidikan secara formal. Keberhasilan pendidikan dapat tercapai apabila seluruh komponen pendidikan, antara lain: guru, siswa, metode pembelajaran, sarana prasarana belajar dan lingkungan dapat berjalan secara berkesinambungan. Guru dan metode pembelajaran. merupakan dua komponen penting yang menentukan kualitas dan prestasi belajar. Guru hendaknya mampu mengembangkan metode pembelajaran yang ada untuk meningkatkan kualitas pembelajaran di kelas.

Salah satu bidang ilmu yang dipelajari oleh peserta didik adalah mata pelajaran IPS di tingkat Sekolah Menengah Pertama (SMP) merupakan mata pelajaran yang mencakup materi yang cukup luas. Guru diharuskan menyelesaikan target ketuntasan belajar siswa, sehingga perlu perencanaan dan pelaksanaan pembelajaran dengan menggunakan model, metode, media atau alat peraga dan strategi yang tepat. Guru juga harus mampu memahami karakteristik siswa dan memberikan rangsangan kepada siswa agar bersemangat dalam mengikuti proses pembelajaran IPS.

Akan tetapi pada saat berlangsungnya proses pembelajaran IPS guru masih menetapkan metode pembelajaran yang monoton yaitu ceramah. Dimana guru menerangkan, siswa duduk, mencatat, dan mendengarkan apa yang disampaikan guru sehingga ketika siswa diminta untuk bertanya oleh guru banyak yang tidak melakukannya hingga proses belajar mengajar berakhir tanpa ada kesempatan untuk mengembangkan daya kreatifitas yang dimiliki siswa. Dengan kondisi 
seperti itu proses pembelajaran yang dilakukan cenderung pada pencapaian target materi kurikulum, dan lebih mementingkan pada penghafalan konsep bukan pada pemahaman. Suasana pembelajaran menjadi tidak kondusif, minat belajar, dan aktifitas siswa dalam pembelajaran IPS masih sangat kurang, sehingga proses belajar dan hasil belajar juga rendah.

Salah satu model pembelajaran yang dipandang dapat mengatasi permasalahan pembelajaran ialah dengan menggunakan model Quantum Teaching. Menurut Riyanto (2010: 200) “Quantum Teaching adalah orkestrasi bermacam-macam interaksi (mencakup unsur-unsur belajar efektif yang mempengaruhi kesuksesan siswa) yang ada didalam dan di sekitar momen belajar." Pendapat lain menurut Wena (2011: 160) menyatakan bahwa "Quantum Teaching merupakan cara baru yang memudahkan proses belajar, yang memadukan unsur seni dan pencapaian yang terarah, untuk segala mata pelajaran." Sedangkan menurut DePorter, dkk (2010: 34) "Quantum Teaching bersandar pada konsep Bawalah Dunia Mereka ke Dunia kita, dan Antarkanlah Dunia Mereka ke Dunia Kita.” Berarti bahwa sangat penting bagi seorang guru untuk dapat memasuki dunia murid sebagai langkah pertama untuk mendapatkan hal mengajar. Menurut DePorter, dkk (2010: 39) "Pada dasarnya dalam pelaksanaan komponen rancangan pembelajaran Quantum dikenal dengan singkatan "TANDUR" yang merupakan kepanjangan dari: Tumbuhkan, Alami, Namai, Demonstrasikan, Ulangi, dan Rayakan." Quantum Teaching dengan kerangkanya yaitu TANDUR diharapkan mampu menciptakan suasana yang menyenangkan dan merangsang siswa dalam proses pembelajaran khususnya mata pelajaran Ilmu Pengetahuan Sosial (IPS).

\section{TINJAUAN PUSTAKA}

\section{Hakikat Hasil Belajar}

\section{Pengertian Belajar}

Menurut Djamarah dan Aswan (2006: 38) "belajar pada hakikatnya adalah perubahan yang terjadi di dalam diri seseorang setelah berakhirnya melakukan aktivitas belajar." Kegiatan belajar merupakan proses siswa untuk mencapai berbagai macam keterampilan dan sikap dalam membentuk pribadi yang baik, berhasil atau tidaknya pencapaian tujuan banyak dipengaruhi oleh bagaimana sistem belajar yang diikuti oleh para siswa yang bersangkutan. 
Belajar memang selalu berkaitan dengan perubahan, baik meliputi keseluruhan tingkah laku individu maupun yang hanya terjadi pada beberapa aspek dari kepribadian individu. Perubahan ini dengan sendirinya dialami tiap-tiap individu atau manusia sejak dilahirkan sampai sekarang ini. Sejak saat itu terjadi perubahan-perubahan dalam arti perkembangan melalui fase-fasenya. Dan oleh sebab itu pula pada saat itu berlangsung proses-proses belajar, proses dalam belajar merupakan faktor penting dan menekankan pada kreativitas individu.

Dalam melaksanakan proses belajar mengajar, diperlukan adanya evaluasi yang nantinya akan dijadikan sebagai tolak ukur maksimal yang telah dicapai siswa setelah melakukan kegiatan belajar, selama waktu yang telah ditentukan. Apabila pemberian materi telah dirasakan cukup, guru dapat melakukan tes yang digunakan sebagai ukuran dari prestasi belajar yang bukan hanya terdiri dari nilai mata pelajaran saja melainkan mencakup nilai, tingkah laku dan pengatuaran diri dalam proses belajar mengajar.

Menurut Trianto (2009: 12) belajar hakikatnya adalah "suatu proses yang ditandai dengan adanya perubahan pada diri seseorang. Perubahan sebagai hasil dari proses belajar yang dimaksud seperti perubahan pengetahuan, pemahaman, sikap dan tingkah laku, kecakapan, keterampilan dan kemampuan, serta perubahan aspek-aspek yang lain.”

Pendapat lain menurut Trianto (2009: 12) menyatakan bahwa "belajar pada dasarnya adalah proses perubahan tingkah laku seseorang berkat adanya suatu pengalaman.” Jadi belajar merupakan suatu proses perubahan tingkah laku atau aspek-aspek lain pada diri seseorang sebagai hasil dari adanya pengalaman dan latihan-latihan.

Menurut Slameto (2003: 2) "belajar adalah suatu proses yang dilakukan seseorang untuk memperoleh suatu perubahan tingkah laku yang baru secara keseluruhan, sebagai hasil pengalamannya sendiri dalam interaksi dengan lingkungannya." Oleh sebab itu belajar adalah proses yang aktif, proses mereaksi terhadap semua situasi yang ada di sekitar individu, proses yang diarahkan kepada tujuan, dan proses berbuat melalui berbagai pengalaman.

Belajar adalah proses melihat, mengamati, memahami sesuatu. Apabila kita berbicara tentang belajar maka kita berbicara bagaimana mengubah tingkah laku seseorang. Inilah hakikat belajar, sebagai inti proses pengajaran atau interaksi 
belajar mengajar yang menjadi persoalan utama ialah adanya proses belajar pada siswa yakni proses berubahnya tingkah laku siswa melalui berbagai pengalaman yang diperolehnya.

Sedangkan menurut Dalyono (2009: 49) "Belajar merupakan usaha atau kegiatan yang bertujuan mengadakan perubahan didalam diri seseorang, mencakup perubahan tingkah laku, sikap, kebiasaan, ilmu pengetahuan, keterampilan, dan sebagainya." Dan menurut Whittakers, James yang dikutip dari buku Abu Ahmadi dan Widodo Supriyono (2004: 126) "belajar adalah sebagian proses dimana tingkah laku ditimbulkan atau diubah melalui latihan atau pengalaman." Sumber belajar adalah segala sesuatu yang dapat dipergunakan sebagai tempat dimana bahan pengajaran terdapat atau asal untuk seseorang belajar.

Berdasarkan definisi diatas, maka dapat disimpulkan bahwa definisi belajar adalah suatu kegiatan yang dilakukan secara sungguh-sungguh dengan sistematis, semua potensi yang dimiliki, baik fisik maupun mental, dana, pancaindra, otak, anggota tubuh, aspek-aspek kejiwaan seperti intelegensi, bakat, motivasi, minat yang bertujuan untuk mengadakan suatu perubahan kearah yang positif didalam diri seseorang agar mampu bersaing didalam kehidupan ini.

\section{Ciri-ciri Belajar}

Menurut Djamarah (2011: 15) ciri-ciri belajar sebagai berikut: 1) Perubahan yang terjadi secara sadar. 2) Perubahan dalam belajar bersifat fungsional. 3) Perubahan dalam belajar bersifat positif dan aktif. 4) Perubahan dalam belajar bukan bersifat sementara. 5) Perubahan dalam belajar bertujuan dan terarah. 6) Perubahan mencakup seluruh aspek.

\section{Faktor-faktor yang Mempengaruhi Belajar}

Menurut Ahmadi dan Supriyono (2004: 139), mengatakan bahwa tingkat keberhasilan atau tidaknya seseorang dalam belajar disebabkan oleh beberapa faktor yang mempengaruhi hasil belajar yaitu, sebagai berikut :

1) Faktor-faktor stimulus belajar yaitu segala hal diluar individu itu untuk mengadakan reaksi atau perbuatan belajar. Stimulus dalam hal ini mencakup material, penugasan, serta suasana lingkungan eksternal yang harus diterima dipelajari oleh siswa. 
2) Faktor-faktor metode belajar yaitu penerapan metode yang tepat terhadap kebutuhan belajar siswa akan mempengaruhi keberhasilan pada prestasi peserta didik.

3) Faktor-faktor individu yaitu keinginan oleh pribadi peserta didik dalam belajar agar mendapatkan nilai yang bagus.

Faktor tersebut banyak menarik perhatian para ahli pendidikan untuk diteliti, seberapa jauh kontribusi/sumbangan yang diberikan oleh faktor tersebut terhadap hasil belajar siswa. Adanya pengaruh dalam diri siswa, merupakan hal yang logis dan wajar, sebab hakikat perbuatan belajar adalah perubahan tingkah laku individu yang diniati dan disadarinya. Siswa harus merasakan adanya suatu kebutuhan untuk belajar dan berprestasi. Ia harus berusaha mengerahkan segala daya dan upaya untuk dapat mencapainya.

\section{Pengertian Model Quantum Teaching}

Joice dan Weil (dalam Rusman, 2012: 133) mengungkapkan bahwa "model pembelajaran dapat dijadikan pola pilihan, artinya guru boleh memilih model pembelajaran yang sesuai dan efisien untuk mencapai tujuan pembelajarannya." Jadi model pembelajaran merupakan suatu rencana yang dipilih oleh guru sesuai pertimbangan tertentu untuk mencapai tujuan pembelajaran yang diinginkan. Pembelajaran Quantum merupakan inovasi dari pengubahan bermacam-macam interaksi yang ada didalam dan disekitar momen belajar. Model Quantum Teaching yang dimaksud adalah suatu rencana atau rancangan pembelajaran yang dipilih oleh guru yang mengkonsentrasikan berbagai interaksi (mencakup unsurunsur belajar efektif) yang mempengaruhi kesuksesan siswa baik didalam maupun disekitar momen belajar. Model Quantum Teaching ini membantu agar proses pembelajaran berlangsung secara meriah sehingga membangkitkan minat siswa dalam belajar.

Menurut Aqib (2002: 129) bahwa "Quantum Teaching adalah pengubahan bahan yang meriah dengan segala nuansanya, interaksi, dan perbedaan yang memaksimalkan momen belajar." Quantum Teaching terfokus pada hubungan dinamis dalam lingkungan kelas secara interaktif yang mendirikan landasan dan kerangka untuk belajar. Quantum Teaching merangkaikan teori dan konsep yang paling baik dari yang terbaik menjadi multi kecerdasan yang pada akhirnya akan melejitkan kemampuan guru untuk mengilhami dan kemampuan murid untuk 
berprestasi. Sebagaimana pendekatan belajar yang segar, mengalir, praktis, dan mudah diterapkan. Quantum Teaching menawarkan suatu sintesis dari hal-hal yang selama ini dicari, yaitu cara-cara baru untuk memaksimalkan dampak usaha pengajaran melalui perkembangan hubungan, pengubahan belajar, dan penyampaian kurikulum.

Jadi dapat dikatakan bahwa Quantum Teaching merupakan pengubahan belajar yang meriah dengan segala kaitan, interaksi, dan perbedaan yang memaksimalkan suasana belajar serta berfokus pada hubungan dinamis dalam lingkungan kelas dan interaksi yang mendirikan landasan dan kerangka belajar.

\section{Asas Quantum Teaching}

DePorter, dkk (2010: 34) Quantum Teaching berstandar pada asas "Bawalah dunia mereka ke dunia kita, dan antarkan dunia kita ke dunia mereka." Hal ini menunjukkan, setiap bentuk interaksi siswa, setiap rancangan kurikulum, dan setiap metode pembelajaran harus dibangun diatas prinsip utama tersebut. Asas tersebut merupakan alasan dibalik segala strategi, model, dan keyakinan Quantum Teaching.

Asas bawalah dunia mereka ke dunia kita, dan antarkan dunia kita ke dunia mereka memberikan kita suatu pengertian bahwa langkah pertama yang harus ditempuh oleh guru adalah memasuki dunia para siswa. Guru harus dapat mengkaitkan apa yang akan diajarkan dengan sebuah peristiwa, pikiran atau perasaan yang diperoleh dari kehidupan rumah, sosial, seni, atau rekreasi para siswa karena tindakan ini memudahkan guru untuk memotivasi, membimbing, dan menuntun para siswa memahami konsep yang lebih luas. Hal tersebut sejalan dengan pendapat DePorter, dkk. (2010: 35) bahwa "tindakan awal tersebut akan memberi izin guru untuk memimpin, menuntun dan memudahkan perjalanan siswa menuju kesadaran dan ilmu pengetahuan yang luas."

Dari uraian di atas, maka dapat dikatakan bahwa jika guru dapat memasuki dunia siswa maka guru secara tidak langsung telah mendapatkan izin dalam memimpin, menuntun, dan memudahkan siswa untuk mengikuti dan memahami pelajaran yang akan diberikan. Dengan pengertian dan penguasaan yang lebih dalam, maka siswa dapat membawa apa yang mereka pelajari kedalam dunia mereka dan menerapkannya. 


\section{Ciri-Ciri Model Quantum Teaching}

Menurut Sugandi (2008: 91) model pembelajaran yang menggunakan model kuantum menunjukkan ciri-ciri sebagai berikut: 1) Penggunaan musik dengan tujuan tertentu. 2) Pemanfaatan ikon-ikon sugestif yang membangkitkan semangat belajar siswa. 3) Penggunaan bahasa yang unggul. 4) Suasana belajar yang saling memberdayakan. 5) Penyajian materi pelajaran yang prima.

\section{Kelebihan dan Kekurangan Model Quantum Teaching}

Menurut DePorter (2010: 35) menyatakan kelebihan dan kekurangan model Quantum Teaching sebagai berikut:

1) Kelebihan Quantum Teaching
a) Selalu berpusat pada apa yang masuk akal bagi siswa
b) Menumbuhkan dan menimbulkan antusiasme siswa
c) Adanya kerjasama
d) Menawarkan ide dan proses cemerlang dalam bentuk yang mudah dipahami siswa
e) Menciptakan tingkah laku dan sikap kepercayaan dalam diri sendiri
f) Belajar terasa menyenangkan
g) Ketenangan psikologi
h) Adanya kebebasan dalam berekspresi

2) Kekurangan Quantum Teaching
a) Memerlukan persiapan yang matang bagi guru dan lingkungan yang mendukung
b) Memerlukan fasilitas yang memadai
c) Kurang dapat mengontrol siswa

\section{Kerangka Model Quantum Teaching}

Menurut DePorter dalam Rusman (2012: 331) "kerangka perancangan pembelajaran Quantum Teaching dinamakan dengan TANDUR yaitu: Tumbuhkan, Alami, Demonstrasikan, Ulangi, dan Rayakan.” Penjelasan dari masing-masing kata tersebut adalah sebagai berikut:

1) Tumbuhkan

Tumbuhkan berarti sertakan diri mereka, pikat dan puaskan dengan AMBAK (Apakah Manfaatnya BagiKu). Artinya bahwa tumbuhkan minat belajar siswa dengan memberikan rasa puas pada pertanyaan "Apakah 
Manfaat BagiKu" (AMBAK) yang ada pada pikiran mereka. Pada tahap ini guru hendaknya menyampaikan tujuan pembelajaran dan manfaat yang akan diperoleh setelah mempelajari materi atau meningkatkan materi penunjang yang sebelumnya sudah diperoleh dari siswa. Oleh karena itu, peran guru dalam memberikan motivasi, semangat, dan rangsangan belajar kepada siswa menjadi hal sangat penting.

2) Alami

Unsur ini memberikan pengalaman kepada siswa dan mendorong hasrat alami otak untuk "menjelajah". Proses pembelajaran akan lebih bermakna jika siswa mengalami secara langsung materi yang diajarkan. Menurut Wena (2011: 165) "pengalaman dapat menciptakan ikatan emosional, menciptakan peluang untuk pemberian makna, dan pengalaman membangun keingintahuan siswa."

3) Namai

Menurut Rusman (2012: 331) "namai yang dimaksudkan adalah tahap untuk menyediakan kata kunci dan mengajarkan konsep, keterampilan berpikir, startegi belajar yang menjadi pesan pembelajaran. Berikan data tepat ketika minat memuncak." Dengan melakukan praktek secara langsung maka siswa benar-benar bisa mencari rumus, menghitung dan memperoleh informasi baru (nama) yaitu dengan pengalaman yang dialami sehingga membuat pengetahuan yang diperoleh siswa menjadi siswa menjadi berarti.

4) Demonstrasikan

Demonstrasikan berarti berikan kesempatan bagi mereka untuk mengaitkan pengalaman dengan data baru, sehingga mereka menghayati dan membuatnya sebagai pengalaman dengan data baru, sehingga mereka menghayati dan membuatnya sebagai pengalaman pribadi. Artinya bahwa pada tahap ini guru memberikan peluang kepada siswa untuk menunjukkan kemampuannya dalam bentuk aktivitas belajar seperti menjawab pertanyaan, mengerjakan soal ke papan tulis, mengajukan pertanyaan, dan memberikan pendapat atau tanggapan.

5) Ulangi

Ulangi menunjukkan kepada siswa pengulangan materi yang diberikan dan menegaskan kepada siswa bahwa mereka benar-benar tahu tentang apa 
yang mereka pelajari. Maksud pengulangan tersebut tidak hanya bisa dilakukan disekolah, namun bisa juga dirumah. Mengulang materi pembelajaran yang telah dibahas dalam pembelajaran akan menguatkan koneksi saraf dan penguatan konsep yang telah dipelajari sehingga akan selalu diingat siswa.

6) Rayakan

Rayakan berarti berikan penghargaan atas prestasi yang positif, sehingga terus diulangi. Memberikan pengakuan atas upaya atau usaha yang dilakukan siswa baik yang dilakukan siswa baik yang dilakukan secara individu maupun berdiskusi. Perayaan berarti pemberian umpan balik yang positif kepada siswa atas keberhasilannya baik berupa pujian maupun pemberian hadiah, tepuk tangan, ataupun bentuk lainnya untuk memotivasi siswa agar lebih giat lagi dalam belajarnya.

\section{METODE}

Metode penelitian ini adalah metode eksperimen, karena disini peneliti menggunakan dua kelas sebagai objek penelitian, yang pertama sebagai kelas eksperimen dan yang kedua sebagai kelas kontrol. Metode ini bertujuan untuk mengetahui ada tidaknya pengaruh penggunaan model Quantum Teaching terhadap peningkatan hasil belajar siswa kelas VIII SMP PGRI 3 Jakarta. Rancangan penelitian kelompok pertama diberi perlakuan (kelompok eksperimen), sedangkan kelompok kedua tidak diberi perlakuan (kelompok kontrol).

Tabel 1. Desain Penelitian

\begin{tabular}{ccc}
\hline Kelompok & Perlakuan & Test \\
\hline KE & $\mathrm{X}$ & $\mathrm{O}_{1}$ \\
KK & - & $\mathrm{O}_{2}$ \\
\hline Sumber: Sugiyono $(2016: 76)$ & &
\end{tabular}

Keterangan:

$\mathrm{KE}$ : Kelompok Eksperimen

KK : Kelompok Kontrol

X : Perlakuan pada kelas yang diajarkan dengan Metode Quantum Teaching

$\mathrm{O}_{1} \quad$ : Tes pada kelas yang diajarkan dengan menggunakan Metode Quantum Teaching

$\mathrm{O}_{2}$ : Tes pada kelas yang diajarkan dengan menggunakan metode konvensional (ceramah) 


\section{Populasi dan Sampel}

1. Populasi

Margono (2009: 118) mendefinisikan "populasi adalah seluruh data yang menjadi perhatian kita dalam suatu ruang lingkup dan waktu yang kita tentukan." Maka dalam penelitian ini yang menjadi populasinya yaitu seluruh peserta didik kelas VIII SMP PGRI 3 Jakarta yang berjumlah 104 peserta didik.

2. Sampel

Menurut Arifin (2012: 224) dalam pengambilan dan penentuan jumlah sampel, sebenarnya tidak ada ketentuan yang mutlak, tetapi sekedar gambaran dapat mengikuti petunjuk sebagai berikut:

a) Jika jumlah anggota populasi sampai dengan 50, sebaiknya dijadikan sampel semua atau sering disebut dengan sampel total, artinya seluruh anggota populasi dijadikan anggota penelitian.

b) Jika jumlah anggota populasi berada antara 51 sampai dengan 100, maka sampel dapat diambil 50\% - 60\% atau dapat juga menggunakan sampel total.

c) Jika jumlah anggota populasi berada antara 101 sampai dengan 500, maka sampel dapat diambil 30\%-40\%.

d) Jika jumlah anggota populasi berada antara 501 sampai dengan 1000, maka sampel dapat diambil $20 \%-25 \%$.

e) Jika jumlah anggota populasi diatas 1000, maka dapat diambil 10\% $15 \%$.

Karena dalam penelitian ini populasi yang diambil sebanyak 104 peserta didik, maka banyaknya sampel yang digunakan adalah 40\% sehingga $104 \mathrm{x}$ $40 \%=41,6$ dibulatkan menjadi 42. Jadi pada penelitian ini di ambil dua kelas sebagai sampel yaitu peserta didik kelas VIII $^{\mathrm{A}}$ sebagai kelas eksperimen dengan jumlah 21 peserta didik, dan kelas VIII ${ }^{\mathrm{B}}$ sebagai kelas kontrol dengan jumlah 21 peserta didik.

\section{Teknik Sampling}

Teknik yang diambil peneliti dengan menggunakan teknik simple random sampling dari populasi terjangkau yang homogen, yang memberi peluang sama kepada anggota populasi untuk menjadi anggota sampel. 
Sugiyono (2016: 82) menyatakan bahwa "dikatakan simple (sederhana) karena pengambilan anggota sampel dari populasi dilakukan secara acak tanpa memperhatikan starta yang ada dalam populasi itu.

\section{HASIL DAN PEMBAHASAN}

\section{Analisis Statistik Deskriptif}

Tabel 2. Analisis Statistik Deskriptif Data Hasil Belajar IPS Peserta Didik Kelas Eksperimen Dan Kelas Kontrol

\begin{tabular}{lcc}
\hline Statistik Deskriptif & $\begin{array}{c}\text { Hasil Belajar IPS } \\
\text { Kelas Eksperimen }\end{array}$ & $\begin{array}{c}\text { Hasil IPS Belajar } \\
\text { Kelas Kontrol }\end{array}$ \\
\hline Maksimum & 97 & 90 \\
Minimum & 53 & 55 \\
Mean & 76,45 & 67,5 \\
Median & 72,7 & 65,54 \\
Modus & 73,18 & 61,46 \\
Varians & 150,24 & 102 \\
Simpangan Baku & 12,25 & 10,09 \\
\hline
\end{tabular}

Dari tabel 2, terlihat bahwa hasil belajar IPS di kelas eksperimen tergolong baik, hal ini terlihat dari nilai mean, median, dan modus yang nilainya mendekati skor maksimum yang mungkin dicapai untuk variabel $\mathrm{X}$ yang menggunakan model pembelajaran Quantum Teaching. Kemudian, hasil belajar IPS di kelas kontrol tergolong cukup baik, terlihat nilai mean, median, dan modus yang nilainya mendekati skor maksimum yang mungkin dicapai untuk variabel Y yang menggunakan metode pembelajaran ceramah.

\section{Uji Persyaratan Analisis Data}

\section{Uji Normalitas}

Pengujian normalitas dilakukan untuk mengetahui distribusi data setiap variabel yang diteliti apakah berdistribusi normal atau tidak. Pengujian normalitas menggunakan uji Chi Kuadrat $\left(x^{2}\right)$ karena data dalam bentuk kelompok dan dihitung dengan tabel penolong dengan kriteria pengujian jika $x^{2}{ }_{\text {hitung }}<x^{2}$ tabel maka data tersebut berdistribusi normal, dan jika $x^{2}{ }_{\text {hitung }}>x^{2}$ tabel maka data tersebut tidak berdistribusi normal. Untuk taraf nyata $\alpha=5 \%$, dalam perhitungan pada kelas eksperimen dengan $n=21$, perhitungan diperoleh $x^{2}{ }_{\text {hitung }}=4,85$ 
karena $x^{2}{ }_{\text {hitung }}<x^{2}$ tabel yaitu $4,85<11,070$, maka $H_{0}$ diterima. Berarti sampel yang digunakan berasal dari populasi yang berdistribusi normal. Dan dalam perhitungan pada kelas kontrol dengan $n=21$, perhitungan diperoleh $x^{2}$ hitung $=$ 8,624 karena $x^{2}{ }_{\text {hitung }}<x^{2}$ tabel yaitu $8,624<11,070$, maka $H_{0}$ diterima. Berarti sampel yang digunakan berasal dari populasi yang berdistribusi normal.

Tabel 3. Ringkasan Hasil Uji Normalitas

\begin{tabular}{cccc}
\hline Variabel & Nilai $\mathbf{X}_{\text {hitung }}^{\mathbf{2}}$ & Nilai $\mathbf{X}_{\text {tabel }}^{\mathbf{2}}$ & keterangan \\
\hline $\begin{array}{c}\text { Hasil Belajar IPS Kelas } \\
\text { Eksperimen }\end{array}$ & 4,85 & 11,07 & $\begin{array}{c}\text { Berdistribusi } \\
\text { Normal }\end{array}$ \\
$\begin{array}{c}\text { Hasil Belajar IPS Kelas } \\
\text { Kontrol }\end{array}$ & 8,624 & 11,07 & $\begin{array}{c}\text { Berdistribusi } \\
\text { Normal }\end{array}$ \\
\hline
\end{tabular}

\section{Uji Homogenitas}

Pengujian homogenitas dengan uji F (Fisher) dapat dilakukan apabila data yang akan diuji hanya ada 2 (dua) kelompok data/sampel. Uji F dilakukan dengan cara membandingkan varian data terbesar dibagi varian data terkecil. Dengan kriteria pengujian terima $\mathrm{H}_{0}$, jika $F_{\text {hitung }}<\mathrm{F}_{\text {tabel }}$ dan tolak $\mathrm{H}_{1}$, jika $\mathrm{F}_{\text {hitung }}>\mathrm{F}_{\text {tabel }}$ dengan taraf nyata $\alpha=5 \%$.

$$
\begin{aligned}
F_{\text {hitung }} & =\frac{\text { varian terbesar }}{\text { varian terkecil }} \\
& =\frac{150,24}{102}=1,47
\end{aligned}
$$

Tabel 4. Ringkasan Hasil Uji Homogenitas

\begin{tabular}{ccc}
\hline Nilai $\mathbf{F}_{\text {hitung }}$ & Nilai $\mathbf{F}_{\text {tabel }}$ & Keterangan \\
\hline 1,47 & 2,12 & Homogen \\
\hline
\end{tabular}

Dari tabel 4, terlihat bahwa nilai $\mathrm{F}_{\text {hitung }}<\mathrm{F}_{\text {tabel }}$ sehingga dapat disimpulkan varians-varians tersebut adalah homogen.

\section{Uji Hipotesis}

Uji hipotesis dimaksudkan untuk mendapatkan kesimpulan hasil dari penelitian dengan menggunakan teknik korelasional dengan menggunakan rumus t-tes. 
Berdasarkan hasil perhitungan uji $t$, dapat diketahui $t_{\text {hitung }}=3,140$. Selanjutnya dibandingkan dengan $\mathrm{t}_{\text {tabel }}$ dengan taraf kesalahan $5 \%$ dan dilakukan tingkat signifikan uji dua pihak dengan menggunakan tabel, nilai $\mathrm{T}_{\text {tabel }}$ yang dapat diperoleh adalah sebagai berikut:

$\mathrm{n}=42$

$\mathrm{dk}=\mathrm{n}_{\mathrm{A}}+\mathrm{n}_{\mathrm{B}}-2=21+21-2=40$

$\alpha=0,05$

Dari hasil $t_{\text {hitung }}$ dengan $\alpha=0,05, \mathrm{dk}=40$, maka diperoleh $\mathrm{t}_{\text {tabel }}=2,021$. Berdasarkan perhitungan diatas maka $t_{\text {hitung }} 3,140>t_{\text {tabel }} 2,021$. Sehingga $t_{\text {hitung }}$ berada diluar penerimaan $\mathrm{H}_{\mathrm{o}}$ atau dengan kata lain $\mathrm{H}_{\mathrm{o}}$ ditolak. Dan dapat disimpulkan bahwa terdapat perbedaan hasil belajar peserta didik pada mata pelajaran IPS yang diberikan metode pembelajaran quantum teaching dengan metode konvensional, sehingga dapat disimpulkan bahwa terdapat pengaruh yang signifikan metode pembelajaran quantum teaching terhadap hasil belajar peserta didik pada mata pelajaran IPS.

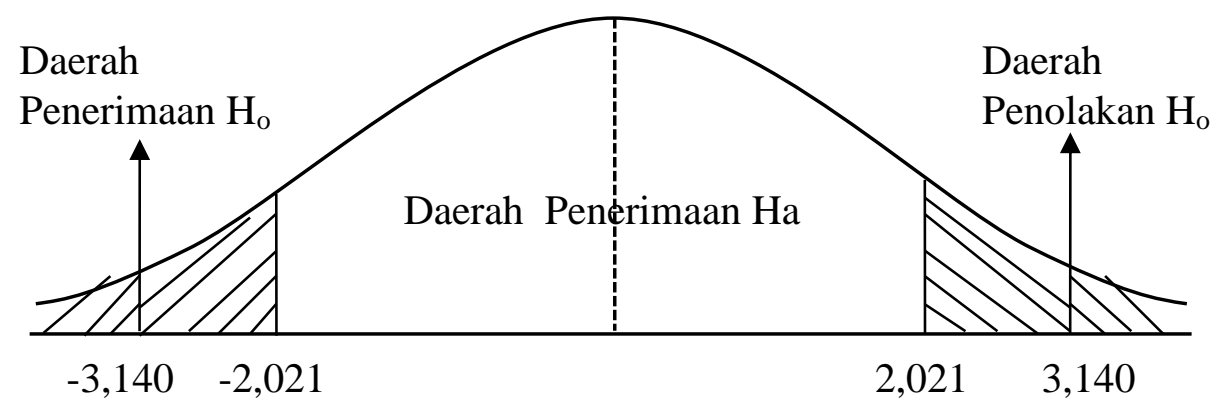

Gambar 1. Kurva Uji Hipotesis

\section{SIMPULAN}

Berdasarkan hasil penelitian dapat disimpulkan perbedaan hasil belajar peserta didik pada mata pelajaran IPS kelas VIII di SMP PGRI 3 Jakarta antara yang menggunakan metode quantum teaching dengan metode pembelajaran konvensional.

Dari data-data yang telah diolah tersebut terdapat hasil belajar peserta didik pada mata pelajaran IPS yang diajarkan menggunakan model pembelajaran quantum teaching lebih tinggi dari pada yang diajarkan menggunakan metode pembelajaran konvensional. Hal ini terlihat dari rata-rata hasil belajar peserta didik yang menggunakan model pembelajaran quantum teaching sebesar 77,28 
lebih tinggi dari pada rata-rata hasil belajar peserta didik yang menggunakan metode pembelajaran konvensional sebesar 66,71.

Dari perolehan pengujian hipotesis dengan menggunakan uji-t yaitu diperoleh nilai $t_{\text {hitung }}=3,140$ lebih besar dari $t_{\text {tabel }}=2,021$ dengan taraf signifikan 0,05. Karena nilai $t_{\text {hitung }}>\mathrm{t}_{\text {tabel }}$ yaitu 3,140 $>2,021$ maka $\mathrm{H}_{0}$ ditolak yang artinya terdapat pengaruh yang signifikan model pembelajaran quantum teaching terhadap hasil belajar peserta didik pada mata pelajaran IPS kelas VIII di SMP PGRI 3 Jakarta.

\section{SARAN}

Berdasarkan simpulan diatas, untuk meningkatkan hasil belajar siswa pada mata pelajaran IPS di SMP PGRI 3 Jakarta maka diajukan saran-saran sebagai berikut yang ditunjukkan kepada:

1. Untuk Kepala Sekolah

Dengan hasil belajar IPS dengan menggunakan model pembelajaran quantum teaching yang lebih baik, hendaknya Kepala Sekolah mengadakan seminar tentang model pembelajaran quantum teaching kepada guru mata pelajaran IPS dan guru mata pelajaran lain agar para guru dapat mendalami metode pembelajaran quantum teaching yang sangat efektif pada proses belajar mengajar.

2. Untuk Guru

Guru harus bisa lebih mengkondisikan kelas, serta mencari informasi tentang metode pembelajaran yang tepat untuk digunakan. Sebaiknya pengajaran yang dilakukan di sekolah menggunakan metode pembelajaran yang menyenangkan dan melibatkan langsung peserta didik dalam proses pembelajaran quantum teaching.

3. Untuk Peserta Didik

Untuk dapat menambah pengetahuan peserta didik diharapkan untuk aktif dalam proses pembelajaran sehingga dapat meningkatkan hasil belajar. Dan dapat didukung dengan menggunakan fasilitas dari sekolah seperti perpustakaan, laboratorium, serta pemanfaatan teknologi informatika seperti jaringan internet dengan sebaik-baiknya.

4. Untuk Orang Tua 
Research and Development Journal Of Education

Vol. 5 No. 1 Oktober 2018

ISSN 2406-9744

Orang tua memberikan dorongan akan pentingnya belajar IPS. Serta orang tua diharapkan dapat berperan aktif dan menunjang kegiatan anak sehari-hari yang ada hubungannya dengan pembelajaran IPS.

\section{DAFTAR PUSTAKA}

Ahmadi, Abu dan Widodo Supriyono. (2004). Psikologi Belajar. Jakarta: PT. Rineka Cipta

Aqib, Zainal. (2002). Profesionalisme Guru dalam Pembelajaran. Surabaya: Insan Cendekia

Arifin, Zainal. (2012). Penelitian Pendidikan Metode dan Paradigma Baru. Bandung: PT. Remaja Rosdakarya

Dalyono. (2009). Psikologi Pendidikan. Jakarta: PT. Rineka Cipta

DePorter, dkk. (2010). Quantum Teaching: Mempraktikan Quantum Learning di Ruang-ruang Kelas. Bandung: Kaifa

Djamarah, Syaiful Bahri dan Zain Aswan. (2006). Strategi Belajar Mengajar. Jakarta: PT. Rineka Cipta

Djamarah, Syiful Bahri. (2011). Psikologi Belajar. Jakarta: PT. Rineka Cipta

Margono. (2009). Metodologi Penelitian Pendidikan. Jakarta: PT. Rineka Cipta

Riyanto, Yatim. (2010). Paradigma Baru Pembelajaran. Jakarta: Kencana

Rusman. (2012). Model-model Pembelajaran: Mengembangkan Profesionalisme Guru. Jakarta: Raja Grafindo Persada

Slameto. (2003). Belajar dan Faktor-Faktor yang Mempengaruhinya. Jakarta: PT. Rineka Cipta

Sugandi, Achmad. (2008). Teori Pembelajaran. Bandung: PT. Remaja Rosdakarya

Sugiyono. (2016). Metode Penelitian Kuantitatif, Kualitatif, dan R\&D. Bandung: Alfabeta

Trianto. (2009). Mendesain Model Pembelajaran Inovatif-Progresif. Jakarta: Kencana Prenada Media Group

Wena, Made. (2011). Strategi Pembelajaran Inovatif Kontamporer. Jakarta: Bumi Aksara 